\title{
UJI KELAYAKAN MULTIMEDIA PEMBELAJARAN INTERAKTIF PADA STANDAR KOMPETENSI MEMASANG INSTALASI PENERANGAN LISTRIK BANGUNAN SEDERHANA DI SMK NASIONAL BERBAH
}

\author{
Ginti Ismayana Serang ${ }^{1}$, Rustam Asnawi ${ }^{2}$ \\ 1,2 Jurusan Pendidikan Teknik Elektro Fakultas Teknik Universitas Negeri Yogyakarta \\ email : gintiismayanaserang@gmail.com, rustam@uny.ac.id
}

\begin{abstract}
This research aims to know the eligibility of multimedia interactive learning from expert and user ratings. This study is a research and development. Development model of this research using a ADDIE model is (1) analysis, (2) design, (3) development and implementation, (4) evaluation. The results of the end-user multimedia interactive learning that the user test one student stated that multimedi interactive learning "good enough", 11 students declared "eligible", and 18 students declared "very eligible". The results obtained ideal percentage of $80.65 \%$ to the category of "eligible" is used as an interactive learning multimedia.
\end{abstract}

Keywords: Multimedia Interactive Learning, ADDIE, Electric Lighting Installation

\section{ABSTRAK}

Penelitian ini bertujuan untuk mengetahui kelayakan multimedia pembelajaran interaktif penilaian ahli dan pengguna. Penelitian ini merupakan jenis penelitian dan pengembangan (research and development). Model pengembangan penelitian ini menggunakan model ADDIE yang terdiri: (1) analisis, (2) desain, (3) pengembangan dan implementasi, (4) evaluasi. Hasil uji pengguna akhir terhadap multimedia pembelajaran interaktif diketahui bahwa pada uji pengguna 1 siswa menyatakan bahwa multimedi pembelajaran interaktif "cukup layak", 11 siswa menyatakan "layak", dan 18 siswa menyatakan "sangat layak". Hasil persentase ideal yang didapatkan sebesar 80,65 \% dengan kategori "layak" digunakan sebagai multimedia pembelajaran interaktif.

Kata kunci: Multimedia pembelajaran interaktif, ADDIE, Instalasi Penerangan Listrik

\section{PENDAHULUAN}

Pendidikan adalah salah satu faktor penting dalam kehidupan. Pendidikan adalah suatu proses dalam rangka mempengaruhi siswa agar dapat menyesuaikan diri sebaik mungkin terhadap lingkungannya dan demikian akan menimbulkan perubahan dalam dirinya yang memungkinkannya untuk berfungsi secara adekuat dalam kehidupan masyarakat. Pengajaran bertugas mengarahkan proses ini agar sasaran dari perubahan itu dapat tercapai sebagaimana yang diinginkan (Hamalik, 2004: 79). Undang - undang No. 20 tahun 2003 tentang sistem pendidikan nasional menyatakan bahwa pendidikan adalah usaha sadar untuk menyiapkan peserta didik melalui kegiatan bimbingan, pengajaran, dan pelatihan bagi peranannya di masa yang akan datang. Dari beberapa pendapat diatas memperlihatkan bahwa pendidikan adalah faktor yang berpengaruh untuk masa depan generasi penerus suatu bangsa.

Proses pembelajaran materi menimbulkan interaksi guru dengan siswa. Hal tersebut adalah salah satu faktor yang mempengaruhi minat atau motivasi belajar siswa dengan materi atau ilmu yang disampaikan. Oleh sebab itu seorang guru harus memiliki strategi untuk meningkatkan motivasi belajar siswa agar tidak bosan dalam mengikuti proses pembelajaran. Salah satu strateginya 
adalah membuat multimedia pembelajaran interaktif memanfaatkan teknologi pendidikan maupun media saat ini.

Menurut Nasution (2011: 1) teknologi pendidikan ialah media komunikasi yang berkembang secara pesat sekali yang dapat dimanfaatkan dalam pendidikan. Alat teknologi ini lazim disebut "hardware" antara lain TV, radio, video tape, komputer, dan lain-lain. Di lain pihak ada pendapat bahwa teknologi pendidikan adalah pengembangan, penerapan, dan penilaian sistem-sistem, teknik dan alat bantu untuk memperbaiki dan meningkatkan proses belajar manusia. Jadi teknologi itu mengenai software maupun hardware. Software antara lain menganalisis dan mendesain urutan atau langkah-langkah belajar berdasarkan tujuan yang ingin dicapai dengan metode yang serasi serta penilaian keberhasilannya.

Sekolah Menengah Kejuruan (SMK) adalah salah satu bentuk satuan pendidikan formal yang menyelenggarakan pendidikan kejuruan pada jenjang pendidikan menengah sebagai lanjutan dari SMP/MTs atau bentuk lain yang sederajat atau lanjutan dari hasil belajar yang diakui sama/setara SMP/MTs. Di SMK terdapat banyak sekali Program Keahlian salah satunya SMK Nasional Berbah Sleman didirikan pertama kali di Yudonegaran Yogakarta pada tahun 1976, kemudian pada tahun 1990 pindah di Tanjungtirto, Kalitirto, Berbah, Sleman. SMK Nasional Berbah dikelola di bawah naungan Yayasan Pendidikan Teknologi Nasional (YPTN). SMK Nasional Berbah memiliki 5 jurusan salah satunya jurusan Teknik Instalasi Tenaga Listrik (TITL). Jurusan TITL terdiri atas 1 kelas disetiap angkatannya dan didampingi 3 orang guru di bidang TITL.

Permasalahan yang timbul di sekolah disebabkan berbagai faktor menurut salah satu guru pada jurusan TITL, permasalahan di jurusan TITL SMK Nasional Berbah kondisi siswa dalam mengikuti pelajaran produktif atau praktik. Kondisi tersebut yaitu siswa pasif dalam mengikuti proses pembelajaran atau cenderung menginginkan memulai praktik tanpa ada penjelasan secara teori tentang praktik yang akan dilakukan. Permasalahan itu disebabkan siswa merasa bosan dengan proses pemberian materi yang kurang menarik yaitu hanya dengan ceramah secara lisan.

Kaitannya dengan multimedia pembelajaran interaktif bisa diterapkan di SMK Nasional Berbah jurusan Teknik Instalasi Tenaga Listrik pada standar kompetensi praktik memasang instalasi penerangan listrik bangunan sederhana karena minat atau motivasi belajar siswa dalam materi teori untuk melandasi pelajaran produktif atau praktik masih kurang. Multimedia pembelajaran interaktif dibuat pada standar kompetensi praktik memasang instalasi penerangan listrik bangunan sederhana diharapkan memudahkan penyampaian guru ke siswa agar siswa tertarik dan meningkatkan motivasi belajar.

Perkembangan Teknologi Informasi yang mampu mengolah, mengemas, dan menampilkan, serta menyebarkan informasi pembelajaran baik secara audio, visual, audiovisual bahkan multimedia, dewasa ini telah mampu mewujudkan apa yang disebut dengan Virtual Learning. Konsep ini berkembang sehingga mampu mengemas setting dan realitas pembelajaran sebelumnya menjadi lebih menarik dan memberikan pengondisian secara psikologis adaptif kepada si pembelajar di mana pun mereka berada. Memang upaya ke arah tersebut banyak dicontohkan dengan munculnya konsep $e$ learning, yang secara realitas dapat disimpulkan bahwa pembelajaran itu tidak sulit walaupun dibatasi oleh ruang dan jarak yang tidak mungkin jika dilakukan secara nature. Realitas yang diharapkan ini justru mampu diwujudkan melalui konsep e-learning (Darmawan, 2012: 41).

Dunia pengajaran dan pembelajaran memiliki peranan yang sangat penting terhadap perkembangan pendidikan, terutama bagi anak didik. Sebab, melalui pengajaran dan pembelajaran itulah, proses pendidikan berlangsung. Karena itu, dunia pengajaran dan pembelajaran menjadi signifikan untuk 
dicermati dan diperhatikan. Salah satunya adalah memahami tentang berbagai media pengajaran dan pembelajaran yang digunakan dalam proses memberikan materi pelajaran kepada anak didik (Indriana, 2011: 5).

Bagaimanapun juga proses pembelajaran tidak terlepas dari keberadaan dan penggunaan sumber belajar. Dengan tersedianya dan dimanfaatkannya sumber belajar yang memadai akan dapat mengatasi hambatan ruang dan waktu yang terkait dengan proses pembelajaran di kelas. Dengan demikian, tersedianya sumber belajar yang memadai akan dapat melengkapi (improvement), memelihara (maintenace), maupun memperkaya (enrichment) proses pembelajaran (Darmawan, 2012: 43).

Dalam suatu proses belajar mengajar, dua unsur yang sangat penting adalah metode mengajar dan media pembelajaran. Kedua aspek ini saling berkaitan. Pemilihan salah satu metode mengajar tertentu akan mempengaruhi jenis media pembelajaran yang sesuai, meskipun masih ada berbagai aspek lain yang harus diperhatikan dalam memilih media, antara lain tujuan pembelajaran, jenis tugas dan respon yang diharapkan siswa kuasai setelah pembelajaran berlangsung, dan konteks pembelajaran termasuk karakteristik siswa (Arsyad, 2011: 15).

Cecep Kustandi dan Bambang Sutjipto dikutip dari Hamalik (2011: 6) mengemukakan bahwa perkembangan ilmu pengetahuan dan teknologi semakin mendorong upaya-upaya pembaharuan dalam pemanfaatan hasil-hasil teknologi dalam proses belajar. Hal tersebut menuntut agar para guru/pengajar mampu menggunakan alat-alat yang disediakan oleh sekolah, dan tidak tertutup kemungkinan bahwa alat-alat tersebut sesuai dengan perkembangan dan tuntutan zaman. Guru sekurang-kurangnya dapat menggunakan media yang murah dan efisien yang meskipun sederhana, tetapi merupakan keharusan dalam upaya mencapai tujuan pembelajaran yang diharapkan.

Media adalah alat saluran komunikasi. Kata media berasal dari bahasa Latin, yang merupakan bentuk jamak dari kata medium. Menurut harfiah, media berarti perantara, yaitu perantara antara sumber pesan (a receiver). Beberapa hal yang termasuk ke dalam media adalah film, televisi, diagram, media cetak (printed materials), komputer, instruktur, dan lain sebagainya (Indriana, 2011: 13). Menurut Azhar Arsyad (2011: 3) mengemukakan bahwa kata media berasal dari bahasa Latin medius yang secara harafiah berarti 'tengah', 'perantara' atau 'pengantar'.

Pembelajaran diartikan sebagai proses penciptaan lingkungan yang memungkinkan terjadinya proses belajar. Jadi dalam pembelajaran yang utama adalah bagaimana siswa belajar. Belajar dalam pengertian aktifitas mental siswa dalam berinteraksi dengan lingkungan yang menghasilkan perubahan perilaku yang bersifat relatif konstan. Dengan demikian aspek yang menjadi penting dalam aktifitas belajar adalah lingkungan. (Daryanto, 2010: 51). Menurut Kamus Besar Bahasa Indonesia kata Interaktif bermakna saling melakukan aksi, antar hubungan, dan saling aktif jadi multimedia interaktif dibuat guna menumbuhkan motivasi siswa untuk aktif berdiskusi dengan guru maupun siswa lain dengan adanya multimedia interaktif tersebut.

Sedangkan multimedia terbagi menjadi dua kategori, yaitu: multimedi linier dan multimedia interaktif. Multimedia linier adalah suatu multimedia yang tidak dilengkapi dengan alat pengontrol apapun yang dapat dioperasikan oleh pengguna. Multimedia interaktif adalah suatu multimedia yang dilengkapi alat pengontrol yang dapat dioerasikan oleh pengguna, sehingga pengguna dapat memilih apa yang akan dikehendaki untuk proses selanjutnya (Daryanto, 2010: 51).

Niken Ariani \& Dany Haryanto (2010 :25) mengartikan multimedia interaktif sebagai suatu multimedia yang dilengkapi dengan alat pengontrol yang dapat dioperasikan oleh pengguna sehingga pengguna dapat memilih apa yang dikehendaki untuk proses selanjutnya. 


\section{METODE PENELITIAN}

\section{Jenis Penelitian}

Penelitian ini menggunakan metode penelitian dan pengembangan atau lebih dikenal dengan istilah research and development (R\&D). Metode penelitian dan pengembangan ini ditujukan untuk menghasilkan produk dan menguji kelayakan produk tersebut. Produk yang dikembangkan adalah multimedia pembelajaran interaktif dengan menggunakan software Adobe Flash pada standar kompetensi memasang instalasi penerangan listrik bangunan sederhana. Multimedia pembelajaran interaktif yang dikembangkan menggunakan model ADDIE yang diadoptasi dari Lee \& Owens. ADDIE merupakan singkatan dari analysis (analisis), design (perancangan/ perencanaan), development and implementation (pengembangan dan implementasi), dan evaluation (evaluasi) struktur model pengembangan ADDIE dapat dilihat pada Gambar 1.



Gambar 1. Model Pengembangan ADDIE

(Sumber: Lee \& Owens 2004)

\section{Waktu dan Tempat Penelitian}

Penelitian pengembangan multimedia pembelajaran interaktif dilaksanakan di SMK Nasional Berbah. Penelitian ini dilakukan pada tanggal 14 Oktober - 15 November 2016

\section{Subjek dan Obyek Penelitian}

Subyek pada penelitian ini adalah ahli materi dan ahli media yang merupakan dosen di Jurusan Pendidikan Teknik Elektro FT UNY yang mengerti dan memahami materi maupun multimedia yang dibuat serta guru dan siswa program keahlian Teknik Instalasi Tenaga Listrik SMK Nasional Berbah. Obyek pada penelitian ini adalah multimedia pembelajaran interaktif yang dibuat peneliti.

\section{Prosedur Penelitian}

Tahap pertama adalah analisis yang terdiri dari (1) Field need, yaitu guna mengetahui apa yang dibutuhkan dari pihak sekolah, guru, maupun penerima multimedia sendiri yaitu siswa; (2) Expressed or demanded need, yaitu untuk mengetahui penawaran dan permintaan dari pihak sekolah, guru, maupun penerima multimedia sendiri yaitu siswa. Dipilihnya dua tipe analisis kebutuhan tersebut agar multimedia yang dibuat dapat diterima dengan baik tanpa ada perbedaan dalam isi materi multimedia dengan materi sekolah dan penggunaan kurikulum yang ada. Sedangkan pada analisis ujung depan dilakukan tiga tipe analisis, yaitu : (1) Audience analysis, yaitu analisis terhadap kondisi nyata siswa saat dikelas pada standar kompetensi memasang instalasi penerangan listrik bangunan sederhana di SMK Nasional Berbah, (2) Situational analysis, untuk mengetahui kendala dalam lingkungan siswa pada standar kompetensi memasang instalasi penerangan listrik bangunan sederhana di SMK Nasional Berbah untuk penyesuaian desain dari multimedia yang dikembangkan, (3) Media analysis, yaitu untuk mengetahui media pembelajaran yang sudah digunakan oleh guru saat menyampaikan materi kepada siswa pada standar kompetensi memasang instalasi penerangan listrik bangunan sederhana di SMK Nasional Berbah.

Tahap kedua adalah tahap desain kerangka multimedia pembelajaran disusun untuk pembuatan struktur komponen yang berada pada multimedia yang akan dibuat, meliputi : materi, alur navigasi, storyboard, dan lain - lain. Dalam penelitian ini digunakan tiga elemen, yaitu : (1) Schedule, yaitu untuk menjelaskan proyek multimedia dan pencapaian pembuatan maupun pengembangan multimedia yang dibuat, (2) Media specifications, yaitu untuk menjelaskan desain dari multimedia atau 
komponen apa saja yang digunakan secara terperinci seperti : teks, grafis, font, animasi, dsb, (3) Lesson structure, menjelaskan bagaimana gambaran konten multimedia dikelompokan dan navigasinya.

Pada tahap pengembangan dan implementasi, media pembelajaran interaktif dikembangkan dengan merealisasikan desain dari storyboard menjadi sebuah multimedia dan memasukan materi yang sudah disusun ke multimedia agar menjadi sebuah multimedia pembelajaran interaktif.

Pada tahap evaluasi dilakukan untuk pengujian pada produk multimedia pembelajaran interaktif. Evaluasi dilakukan dengan beberapa komponen yang menilai dimaksudkan untuk mengetahui sejauh mana produk pembelajaran yang dikembangkan layak digunakan dari segi desain pembelajaran, isi/materi, dan desain visual. Penilaian dilakukan oleh ahli materi, ahli media, dan respon penilaian siswa atau pengguna. Evaluasi dan saran dari ahli media, ahli materi, dan respon penilaian siswa atau pengguna dijadikan sebagai dasar dalam melakukan revisi terhadap media yang dikembangkan sebelum di uji coba.

\section{Data, Instrumen, dan Teknik Pengumpulan Data}

Data yang diperoleh dari penelitian ini adalah data kelayakan dari Multimedia Pembelajaran Interaktif pada standar kompetensi memasang instalasi penerangan listrik bangunan sederhana di SMK Nasional Berbah yang dilihat dari aspek media, aspek materi dan aspek secara keseluruhan. Instrumen penelitian yang digunakan untuk mengumpulkan data pada penelitian ini adalah angket. Angket digunakan untuk mendapatkan data kelayakan multimedia yang dikembangkan dan respon penilaian pengguna. Instrumen penelitian berupa angket ini disusun menggunakan skala Likert dengan empat pilihan jawaban. Terdapat 3 buah angket yaitu angket uji ahli media, angket uji ahli materi, dan angket uji pengguna.

\section{Teknik Analisis Data}

Teknik analisis data yang digunakan untuk mengetahui kelayakan dan respon penilaian pengguna terhadap pengembangan multimedia pembelajaran interaktif dianalisis secara deskriptif. Data diperoleh dari hasil penilaian ahli media, ahli materi dan penilaian respon pengguna (siswa) melalui angket dengan skala Likert empat pilihan jawaban. Kemudian data yang diperoleh dikonversikan menjadi nilai dengan skor likert skala empat. (Sumber: Juknis Penyusunan Perangkat Penilaian-Direktorat Pembinaan SMA, 2010: 60)

\section{HASIL PENELITIAN DAN PEMBAHASAN}

Kelayakan multimedia pembelajaran interaktif dinilai berdasarkan penilaian dari ahli materi, ahli materi dan respon penilaian pengguna. Penilaian kelayakan oleh ahli materi meliputi aspek desain pembelajaran, materi, dan manfaat. Data hasil penilaian kelayakan oleh ahli materi dapat ditunjukkan pada Tabel 2.

Tabel 2. Data Hasil Penilaian Ahli Materi

\begin{tabular}{clcc}
\hline No. & \multicolumn{1}{c}{ Aspek } & $\begin{array}{c}\text { Rerata } \\
\text { Skor }\end{array}$ & Kategori \\
\hline 1 & $\begin{array}{l}\text { Desain } \\
\text { Pembelajaran }\end{array}$ & 20,5 & $\begin{array}{l}\text { Sangat } \\
\text { Layak } \\
\text { Sangat } \\
\text { Layak }\end{array}$ \\
3 & Materi & 31,5 & $\begin{array}{l}\text { Sangat } \\
\text { Layak }\end{array}$ \\
\hline Merata Skor Total & 16,5 & 68,5 & $\begin{array}{l}\text { Sangat } \\
\text { Layak }\end{array}$ \\
\hline
\end{tabular}

Data hasil uji validasi yang dilakukan terhadap ahli materi diperoleh aspek desain pembelajaran mendapatkan rerata skor 20.5 dengan kategori "sangat layak", aspek materi mendapatkan rerata skor 31,5 dengan kategori "sangat layak", dan aspek manfaat mendapatkan rerata skor 16,5 dengan kategori "sangat layak". Rerata skor total dari ketiga aspek adalah 68,5 atau 85,63\% dari jumlah skor tertinggi ideal dengan kategori "sangat layak" 
sehingga dapat dikatakan multimedia pembelajaran interaktif standar kompetensi memasang instalasi penerangan listrik bangunan sederhana termasuk dalam kategori "sangat layak" digunakan sebagai multimedia pembelajaran. Hasil persentase dari ketiga aspek penilaian ahli materi dapat dilihat pada Gambar 2.

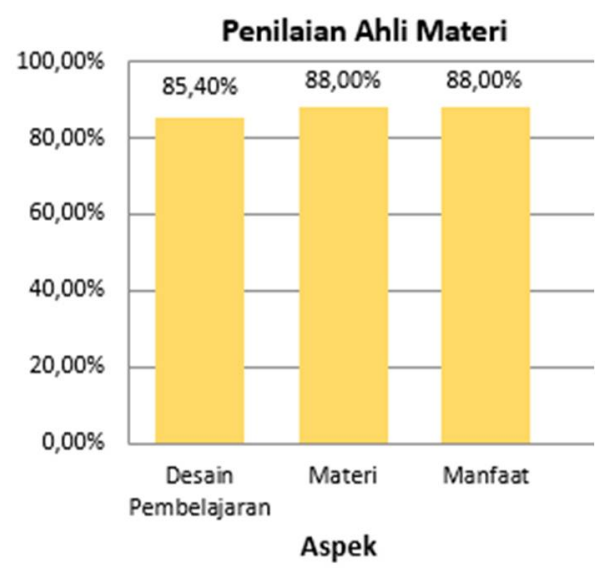

Gambar 2. Grafik Penilaian Ahli Materi

Sementara penilaian kelayakan oleh ahli media meliputi aspek software, desain visual dan manfaat. Data hasil penilaian kelayakan oleh ahli media dapat ditunjukkan pada Tabel 3.

Tabel 3. Data Hasil Penilaian Ahli Media

\begin{tabular}{|c|c|c|c|}
\hline No. & Aspek & Skor & Kategori \\
\hline 1 & Software & 11,5 & Sangat Layak \\
\hline 2 & $\begin{array}{l}\text { Desain } \\
\text { Visual }\end{array}$ & 53 & Sangat Layak \\
\hline 3 & Manfaat & 19 & Sangat Layak \\
\hline \multicolumn{2}{|c|}{ Rerata Skor Total } & 83,5 & Sangat Layak \\
\hline
\end{tabular}

Data hasil uji validasi yang dilakukan terhadap ahli media diperoleh aspek software mendapatkan rerata skor 11.5 dengan kategori "sangat layak", aspek desain visual mendapatkan rerata skor 53 dengan kategori "sangat layak", dan aspek manfaat mendapatkan rerata skor 19 dengan kategori "sangat layak".Rerata skor total dari ketiga aspek diperoleh rerata skor 83,5 atau 90,76\% dari jumlah skor tertinggi ideal dengan kategori "sangat layak" sehingga dapat dikatakan multimedia pembelajaran ini termasuk dalam kategori "sangat layak" digunakan sebagai multimedia pembelajaran. Hasil persentase dari ketiga aspek penilaian ahli materi dapat dilihat pada Gambar 3.

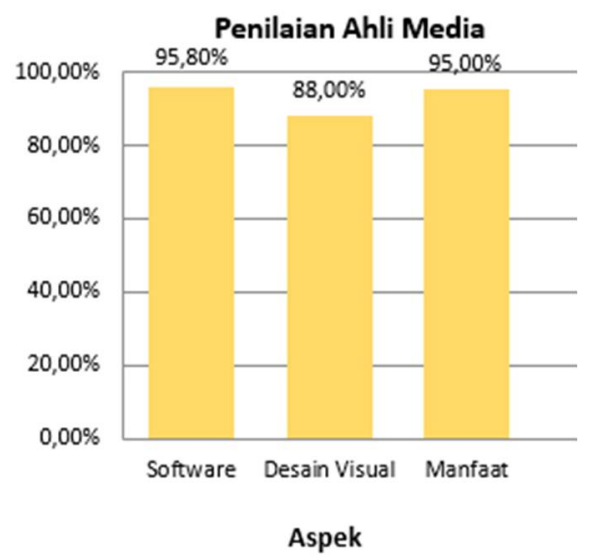

Gambar 3. Grafik Penilaian Ahli Media

Sedangkan pada uji pengguna oleh siswa meliputi aspek software, desain visual, desain pembelajaran, dan manfaat. Data hasil penilaian kelayakan oleh ahli materi dapat ditunjukkan pada Tabel 4.

Tabel 4. Data Hasil Uji Pengguna

\begin{tabular}{clcc}
\hline No. & Aspek & $\begin{array}{c}\text { Rerata } \\
\text { Skor }\end{array}$ & Kategori \\
\hline 1 & Software & 9,6 & Layak \\
& Desain & 32,6 & Sangat Layak \\
& Visual & & \\
& Desain & 15,07 & Layak \\
3 & Pembelajaran & & Sangat Layak \\
4 & Manfaat & 16,93 & Layak \\
\hline Rerata Skor Total & 74,2 & \\
\hline
\end{tabular}

Berdasarkan Tabel 2 rerata aspek software mendapatkan skor 9,6 dengan kategori "layak", rerata aspek desain visual bernilai skor 32,6 dengan kategori "sangat layak", rerata aspek desain pembelajaran bernilai 15,07 dengan kategori "layak", dan rerata aspek manfaat 16,93 dengan kategori "sangat layak". Pada proses uji pengguna multimedi pembelajaran interaktif ini siswa yang berpartisipasi sebanyak 30 siswa dari jumlah total 35 siswa. Hasil dari pengujian respon 
siswa didapatkan 1 siswa menyatakan bahwa multimedi pembelajaran interaktif "cukup layak", 11 siswa menyatakan bahwa multimedi pembelajaran interaktif "layak", dan 18 siswa menyatakan bahwa multimedi pembelajaran interaktif "sangat layak". Hasil presentase ideal yang didapatkan sebesar $80,65 \%$ dengan kategori "layak" digunakan sebagai multimedi pembelajaran interaktif. Hasil persentase dari uji pengguna dapat dilihat pada Gambar 4 .

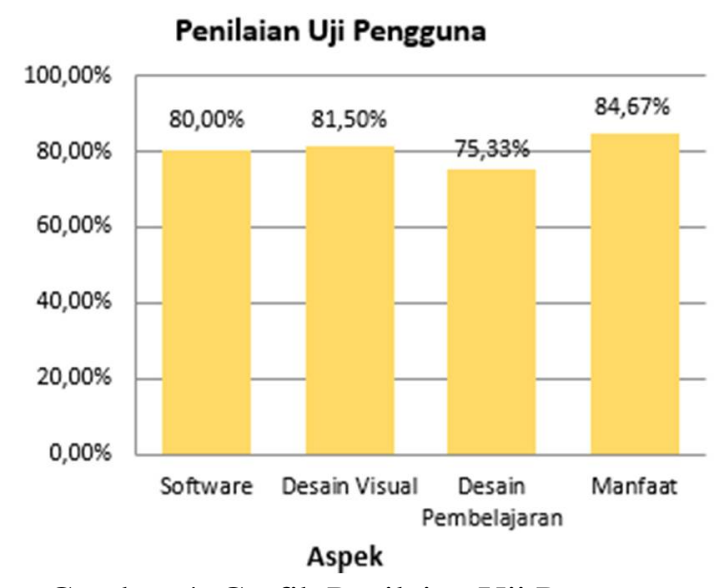

Gambar 4. Grafik Penilaian Uji Pengguna

\section{SIMPULAN}

Berdasarkan hasil penelitian dan pembahasan yang sudah dijabarkan, maka dapat ditarik kesimpulan bahwa, hasil uji kelayakan multimedia pembelajaran interaktif pada standarkompetens memasang instalasi penerangan listrik bangunan sederhana oleh ahli materi mendapatkan rerata skor 68,5 dari total skor rerata sebesar 80 , dengan rincian penilian sebagai berikut: aspek desain pembelajaran 20,5, aspek materi 32, dan aspek manfaat 17 , sehingga mendapatkan kategori "sangat layak" digunakan sebagai multimedia pembelajaran. Penilaian kelayakan oleh ahli media mendapatkan rerata skor 83,5 dari total skor rerata sebesar 92, dengan rincian penilaian sebagai berikut: aspek aspek software 11,5, aspek desain visual 53, dan aspek manfaat 19, sehingga mendapatkan kategori "sangat layak" digunakan sebagai multimedia pembelajaran. Serta uji pengguna 1 siswa menyatakan bahwa multimedi pembelajaran interaktif "cukup layak", 11 siswa menyatakan bahwa multimedi pembelajaran interaktif "layak", dan 18 siswa menyatakan bahwa multimedi pembelajaran interaktif "sangat layak" dari jumlah keseluruhan siswa sebanyak 30 siswa. Sehingga dapat diambil kesimpulan bahwa multimedia pembelajaran interaktif pada standar kompetensi memasang instalasi penerangan listrik bangunan sederhana "layak" digunakan sebagai multimedia pembelajaran.

\section{DAFTAR RUJUKAN}

Ariani Niken dan Dany Haryanto. (2010). Pembelajaran Multimedia di Sekolah. Jakarta: Prestasi Pustaka

Arsyad Azhar. (2011). Media Pembelajaran. Jakarta: Rajawali Pers

Cecep Kustandi dan Bambang Sutjipto. (2011). Media Pembelajaran Manual dan Digital. Bogor: Penerbit Ghalia Indonesia

Daryanto. (2010). Media pembelajaran. Yogyakarta: Gava Media

Deni Darmawan. (2012). Inovasi Pendidikan. Bandung: Remaja Rosdakarya

Dina Indriana. (2011). Ragam Alat Bantu Media Pengajaran. Yogyakarta: Diva Press

Oemar Hamalik. (2004). Proses Belajar Mengajar. Jakarta: Bumi Aksara

Sugiyono. (2006). Metode Penelitian Kuantitatif, Kualitatif dan R\&D. Bandung: Alfabeta,CV

Undang-Undang Republik Indonesia No.20 Tahun 2003 tentang Sistem Pendidikan Nasional. Diakses dari http://kemenag.go.id/file/dokumenUU 2003.pdf. Pada tanggal 18 Januari 2016, pukul 15.00 WIB 